\title{
Correspondence
}

\section{An attempt to produce immune complexes in experimental syphilis}

\author{
TO THE EDITOR, British fournal of Venereal Diseases
}

SIR-The nephrotic syndrome associated with secondary syphilis in man has been previously reported (Robins and Ladd, 1962; Falls, Ford, Ashworth, and Carter, 1965; Braunstein, Lewis, Galvanek, Hamilton, and Bell, 1970; Bhorade, Carag, Lee, Potter, and Dunea, 1971). However, the specificity of the lesions is still in doubt, since the causative antigen involved in syphilitic nephrosis has not been demonstrated so far. Attempts were made to produce immune complexes in experimental animals. 34 adult rabbits were each infected with approximately $2 \times 10^{7}$ Treponema pallidum Nichols strain. To create conditions for severe infection, some of the animals were kept at $17^{\circ} \mathrm{C}$. and others were treated with methotrexate. The animals, depending on the experimental conditions, were divided into four groups.

Two groups of nine rabbits each were infected respectively intratesticularly or intravenously and housed in an environmental chamber with a temperature of $17^{\circ} \mathrm{C} \pm$ $0.5^{\circ} \mathrm{C}$.

A third group of six animals infected intratesticularly and housed at room remperature $\left(22^{\circ} \mathrm{C}\right.$.) were treated with methotrexate 3 weeks before and 8 weeks after infection. Each animal received a total of $287 \mathrm{mg}$. methotrexate divided into twice weekly doses of $4 \mathrm{mg}$. $/ \mathrm{kg}$. body weight.

A fourth group, consisting of ten rabbits, were infected intratesticularly and housed at room temperature. This group was used as a control.

All animals were examined for the presence of lesions twice a week. Sera obtained before the infection and then every two weeks throughout the experimental period were examined for Wassermann antibodies by the VDRL test, for antitreponemal antibodies by the FTA-ABS test, and for haemolytic complement activity. Urine was collected at 2-week intervals and examined for protein content and the presence of white or red blood cells. Between 5 and 6 months after infection the animals were killed. All organs were examined macroscopically and the kidneys histologically. Paraffin-embedded sections were stained with haematoxylin and eosin, and periodic acid-Schiff. Kidney sections (not fixed in buffered formalin) were examined by the immunofluorescent method for immunoglobulin deposits using fluorescein isothiocyanate conjugated goat antiserum to rabbit gamma globulins.

Rabbits infected intratesticularly and housed at $17^{\circ} \mathrm{C}$. or $22^{\circ} \mathrm{C}$. and those treated with methotrexate responded with orchitis between 7 and 12 days after infection. Animals infected intravenously and housed at $17^{\circ} \mathrm{C}$. as well as animals treated with methotrexate developed more severe lesions (syphilomas on eyelids, nose, and hind extremities) than the animals of the control group kept at $22^{\circ} \mathrm{C}$. The haemolytic complement levels did not indicate any presence of antigen-antibody complexes. The complement activity increased rather than decreased. In the methotrexate-treated animals, the haemolytic complement steadily increased from the pre-infection levels of $7.8 \mathrm{U} / \mathrm{ml}$. to reach $13.5 \mathrm{U} / \mathrm{ml}$. after 45 days of infection and later decreased to pre-infection levels. In the animals housed at $17^{\circ} \mathrm{C}$., the complement levels fluctuated between 6.0 and $7.0 \mathrm{U} / \mathrm{ml}$. and in the control animals between 7.0 and $8.0 \mathrm{U} / \mathrm{ml}$. throughout the whole experimental period.

The serological results presented some unexpected phenomena. The animals treated with methotrexate produced a rather low level of Wassermann antibodies. The highest average titre of 20 in this group was already seen 15 days after infection; it remained at the same level during the next 30 days and then decreased. The highest average titre of the Wassermann antibodies in the control animals $\left(22^{\circ} \mathrm{C}\right.$.) was 58 and appeared on the 30th day of infection, whereas the highest average titre in animals housed at $17^{\circ} \mathrm{C}$. was 60 and appeared around the 45th day of infection. The group average titre of the antitreponemal antibodies was very high in the control animals $(10,000)$ and lower (2000-4000) in the three remaining groups. The highest titre in the control group was observed between 45 and 60 days after infection and in the animals housed at $17^{\circ} \mathrm{C}$. or treated with methotrexate between 90 and 120 days.

The urine analyses did not reveal any abnormal function of the kidneys. The gravity, $\mathrm{pH}$, protein content, or the number of white or red blood cells revealed nothing of significance. The histopathology of the kidneys did not reveal any abnormalities in structure and no immunoglobulin deposits were found.

From the negative results we may conclude that in the described experimental conditions no noticeable transient or permanent involvement of immune complexes took place. The $T$. pallidum positive lesions found on the eyelids, nose, and/or extremities of some of the animals would indicate that spirochaetaemia did occur. In the methotrexate-treated animals the peak of the Wassermann antibodies appeared around the second week of infection. Also, in animals of the other groups, antibodies were present at the time of spirochaetaemia, hence conditions for the formation of complexes were created. These 
conditions would be comparable to that of secondary or congenital syphilis in man in which immune complex deposits were reported (Kaplan, Wiglesworth, Markes, and Drummond, 1972; Wiggelinkhuizen, Kaschula, Uys, Kuijten, and Dale, 1973). However, it is possible that the infection in rabbits limits itself much faster than in humans and, being generally without recurrences, immune complexes might not be formed. From another point of view we may speculate that some very small soluble antigen-antibody complexes could be formed without detectable involvement of complement and without damaging consequences to the kidney, especially if such complexes appeared only transiently. In man, relapses in secondary syphilis may occur in approximately 20 per cent. In such privileged conditions the nephrotic syndrome might develop. A similar situation may occur in congenital syphilis. The intra-uterine infection may be present for months before diagnosis. The presence of responsible antigen and antibody may create in the newborn suitable conditions for immune complex glomerulonephritis.

In our experiments we have not produced immune complexes in rabbits infected with $T$. pallidum. However, in process of these experiments, some new immunological phenomena were observed:

(1) A delayed appearance of Wassermann antibodies and a delayed appearance and selective decrease of treponemal antibodies in animals kept at $17^{\circ} \mathrm{C}$. This could most likely explain why rabbits infected with $T$. pallidum produce more severe lesions when kept at a lower temperature.
(2) The action of methotrexate caused an earlier appearance of Wassermann antibodies (19S) but the production was suppressed as compared with infected non-treated rabbits.

(3) Methotrexate also caused a significant increase of haemolytic complement, the mechanism of which remains unknown.

$$
\text { Yours faithfully, }
$$

K. J. WICHER, D.M.SC.

V. WICHER, PH.D.

M. DABRoWSKI, M.D.

ERIE County Laboratory,

Division of Clinical Microbiology,

E. J. Meyer Memorial Hospital, and the Department of Microbiology, School of Medicine, SUNY at BufFalo,

BufFalo, N.Y. 14215, USA

May 30, 1974

\section{References}

Bhorade, M. S., Carag, H. B., Lee, H. J., Potter, E. V., and Dunea, G. (1971) F. Amer. med. Ass., 216, 1159

Braunstein, G. D., Lewis, E. J., Galvanex, E. G., Hamilton, A., and BeLL, W. R. (1970) Amer. F. Med., 48, 643

Falls, W. F. Jr., Ford, K. L., AshwORTh, C. T., and Carter, N. W. (1965) Ann. intern. Med., 63, 1047

KAPLAN, B. S., WIGLESWORTH, F. W., MARKS, M. I., and DRUMMOND, K. N. (1972) f. Pediat., 81, 1154

Robins, D. E., and LADD, A. T. (1962) Amer. F. Med., 32, 817

Wiggelinkhuizen, J., Kaschula, R. O. C., UYs, C. J., KuIJTEN, R. H., and DaLE, J. (1973) Arch. Dis. Childh., 48, 375

\title{
Medical Society for the Study of Venereal Diseases
}

\author{
Programme, 1974-1975
}

General Meetings of the Society, to which guests are welcomed, will be held at 11 Chandos Street, Cavendish Square, London W1M 0EB, on Fridays at 7.30 p.m., refreshments being served from 6.45 p.m., on the following dates:

October 25 Annual General Meeting

Health Education Film 'Bristol 24416', introduced by Dr. A. L. Hilton

'Health Education for Adolescents' by Dr. A. J. Dalzell-Ward

November 29 'Trichomoniasis.' Papers by Dr. J. A. McFadzean, Dr. P. G. Hammond, and Prof. W. H. R. Lumsden

fanuary 31 'Aetiology of Homosexuality' by Dr. John Randell
March 28 'Aortic Valve Replacement in Syphilitic Heart Disease' by Dr. Richard Emanuel Presidential Address, 'Ten-Year Study of Homosexuals' by Dr. J. L. Fluker

In addition, on February 21, 1975, a one-day symposium on 'Recent Advances in Sexually-Transmitted Diseases' will be held in collaboration with the Royal College of Obstetricians and Gynaecologists. Speakers to be arranged.

The Spring Meeting of the Society will be held in Malta, on April 18 to 20,1975 , after the general assembly of the International Union against the Venereal Diseases and Treponematoses. 